\title{
Early Plant Growth and Yield of Sweetpotato Grown from Seed, Vegetative Cuttings, and Somatic Embryos
}

\author{
Jonathan R. Schultheis ${ }^{1}$ and Daniel J. Cantliffe \\ Horticultural Sciences Department, University of Florida, Gainesville, FL 32611 \\ Herbert H. Bryan \\ Tropical Research and Education Center, 18905 SW 280 Street, Homestead, FL 33031
}

Additional index words. Ipomoea batatas, micropropagation, zygotic, clonal propagation, synthetic seed

\begin{abstract}
Early plant growth, root quality, and yield from sweetpotato plants obtained from zygotic seed, somatic embryos, or cloned from stock plants (through micropropagation, rooted node explants, or nonrooted terminal vine cuttings) were compared in field plantings established in 1986, 1987, and 1988 in Gainesville and/or Homestead, Fla. At planting, transplants derived from somatic embryos had more nodes than the other propagules, while vine length per plant was greatest with nonrooted vine cuttings obtained from stock plants. The number of nodes (up to $253 \%$ ) and vine growth (up to $517 \%$ ) were greater when plants were derived from stock plants and zygotic embryos than from somatic embryos 4 weeks (1987) and 6 weeks (1988) after planting. Vegetative growth, larger-sized storage roots $(>6 \mathrm{~cm}$ in diameter), and total yields (all root grades combined) were consistently reduced when plants were derived from somatic embryos compared with propagules of stock plant origin. Plants obtained from somatic embryos required more time for roots to bulk or size than the other propagule types. Root yield from plantlets derived from somatic embryos showed a 14-fold increase when harvest was delayed at least 53 more days. Root weight, regardless of harvest date, was greater when plants were derived from stock plants rather than from somatic embryos, while in most cases plants derived from somatic embryos yielded a greater number of roots than from stock plants. Plants obtained through somatic embryony and harvested at a later date typically had yields exceed $1.8 \mathrm{~kg}$ per plant. Morphology of plants obtained from somatic embryos was uniform and identical to plants derived from stock plants.
\end{abstract}

Sweetpotatoes (Ipomoea batatas Poir.) are typically grown for food, but they can be utilized as a biomass crop (Dangler et al., 1984; O'Hair et al., 1983). Large commercial plantings of sweetpotato for biomass production are cost prohibitive because of the expense of vegetative propagation (Cantliffe et al., 1987). Use of zygotic seed for production is impossible because sweetpotato is a hexaploid and has a complex quantitative inheritance, such that each seed-derived plant is unique.

Regeneration of plants through somatic embryogenesis is a common phenomenon in tissue culture of many species (Ammirato et al., 1983; Tisseret et al., 1979). Liu and Cantliffe (1984) proposed that sweetpotato somatic embryos, when produced in mass quantities in vitro, could be used as propagules for planting. The use of somatic embryos as propagules (synthetic seed) could reduce planting costs, since laborious, time-consuming tasks of conventional propagation (curing and storing roots, planting the roots in beds and inducing them to sprout, and hand-pulling the sprouts and transplanting them into the field) would be eliminated. In addition, large quantities of somatic embryos would be produced in less time and space, and the propagules would remain disease free (Fujii et al., 1987).

There are limited field studies that compare yields of plants

Received for publication 9 Aug. 1993. Accepted for publication 7 Dec. 1993. Florida Agriculture Experiment Station Journal Series No. R-03342. Mention of proprietary products is for convenience of reader only, and does not constitute endorsement by the Univ. of Florida. This work was supported in part by an IFAS/ Gas Research Institute cooperative grant. The authors wish to thank Alfred Jones (U.S. Dept. of Agriculture, Charleston, S.C.) for contributing sweetpotato seeds. The cost of publishing this paper was defrayed in part by the payment of page charges. Under postal regulations, this paper therefore must be hereby marked advertisement solely to indicate this fact.

'Present address: North Carolina State University, Dept. of Horticultural Science, Box 7609, Raleigh, N.C. 27695 obtained from somatic embryos and plants propagated by traditional asexual methods. Rajasekaran et al. (1987) conducted such a study with napier grass and reported that yields were greater from somatic embryo-derived plants than vegetatively propagated plants after the initial harvest.

Normal root production has been reported from plants obtained from sweetpotato somatic embryos when raised in the growth chamber at 27C for 5 months (Liu and Cantliffe, 1984). We conducted field studies over a 3-year period to compare early plant growth and storage root yields of sweetpotato plants derived from zygotic seed, and in various forms from somatic embryos and stock plants.

\section{Materials and Methods}

General planting procedures. A high starch producing sweetpotato cultivar, White Star, was used in all experiments, while zygotic seed were obtained from Alfred Jones of the U.S. Dept. of Agriculture laboratory in Charleston, S.C. In Gainesville, the soil was fumigated and fertilizer was incorporated into raised soil beds at $38 \mathrm{~N}-51 \mathrm{P}-51 \mathrm{~K}\left(\mathrm{~kg} \cdot \mathrm{ha}^{-1}\right)$ before planting. Additional fertilizer, $10.2 \mathrm{~N}-9.5 \mathrm{P}-9.5 \mathrm{~K}\left(\mathrm{~kg} \cdot \mathrm{ha}^{-1}\right)$, was applied each subsequent month in the 1986 and 1987 studies. For the 1988 plantings, there was only one sidedress application because raised beds were covered with black plastic mulch that reduced the leaching of fertilizer. Propagules were irrigated immediately after planting to ensure plant establishment.

In Homestead, in 1988, sweetpotatoes were planted as a second crop following tomatoes in soil beds covered with black plastic mulch. A liquid fertilizer was supplied through drip irrigation at a rate of $5.5 \mathrm{~N}-11.0 \mathrm{P}-2.8 \mathrm{~K}\left(\mathrm{~kg} \cdot \mathrm{ha}^{-1} \cdot \mathrm{month}^{-1}\right)$. Three applications of Fe (Geigy 138, C.B. Geigy, Greensboro, N.C.) were applied in August, October, and December at a rate of $33.6 \mathrm{~g} \cdot \mathrm{ha}^{-1}$. In addition, 
Table 1. Propagation source and type codes.

\begin{tabular}{lclr}
\hline \hline Code & Source & & \multicolumn{1}{c}{ Type of propagation } \\
\hline SET & Somatic embryo & Transplant obtained directly from somatic embryo & Expt. $^{\mathrm{z}}$ \\
SEE & Somatic embryo & Transplant obtained from excised node from plant maintained in the greenhouse & $1,2,3,4$ \\
SEV & Somatic embryo & Terminal vine cutting from plant maintained in the greenhouse & $2,3,4$ \\
SPM & Stock plant & Transplant obtained from excised node from shoot maintained under in vitro conditions & $1,2,3,4$ \\
& & (micropropagation) & $2^{y}, 3,4$ \\
SPE & Stock plant & Transplant obtained from excised node from plant maintained in the greenhouse & $2,3,4$ \\
SPV & Stock plant & Terminal vine cutting from plant maintained in the greenhouse & $1,2,3,4$ \\
ZST & Zygotic seed & Transplant obtained from “true seed” & $2,3,4$ \\
\hline
\end{tabular}

ㄱopagule was included in experiment number listed.

${ }^{y}$ Data for propagule was included only for yield.

magnesium nitrate was applied once at 4.7 liters $\cdot \mathrm{ha}^{-1}$.

Fertilizer was applied at both locations to facilitate optimum growth according to soil test recommendations. Plots were handweeded and irrigated, and the recommended pesticide applications were applied (Stall et al., 1984) to facilitate optimum plant growth and development.

\section{Propagation methods}

Up to seven propagule sources and types were compared (Fig. 1) (Table 1). Three types were derived from the somatic embryo source: 1) $\approx 10$-week-old transplant (SET); 2) transplant obtained by rooting an excised node (SEE); and 3) terminal vine cutting (SEV). Three types were obtained from stock plants: 4) transplant obtained via micropropagation (SPM); 5) transplant obtained by rooting an excised node (SPE); and 6) terminal vine cutting (SPV). The final propagation source and type 7) was obtained from "true" (zygotic) seed as a transplant (ZST).

Somatic embryos were produced from embryogenic callus (Schultheis and Cantliffe, 1992). For plant production, embryos were selected, placed in $100 \times 25$-mm petri plates (Nunc, Naperville, Ill.), and grown on fresh medium composed of Murashige and Skoog (1962) (MS) basal medium with $10 \mathrm{~mm}$ ammonium nitrate (half-strength), vitamins (Linsmaier and Skoog, 1965), 0.7\% (w/ v) Difco bacto agar, and $47 \mathrm{~mm}$ sucrose. Incubation was a 10- to 14$\mathrm{h}$ light/dark photoperiod at $27 \mathrm{C}$, and the light intensity was 120 $\mu \mathrm{E} \cdot \mathrm{m}^{-2} \cdot \mathrm{s}^{-1}$ (Chée et al., 1990). Embryos grew into plants after 3

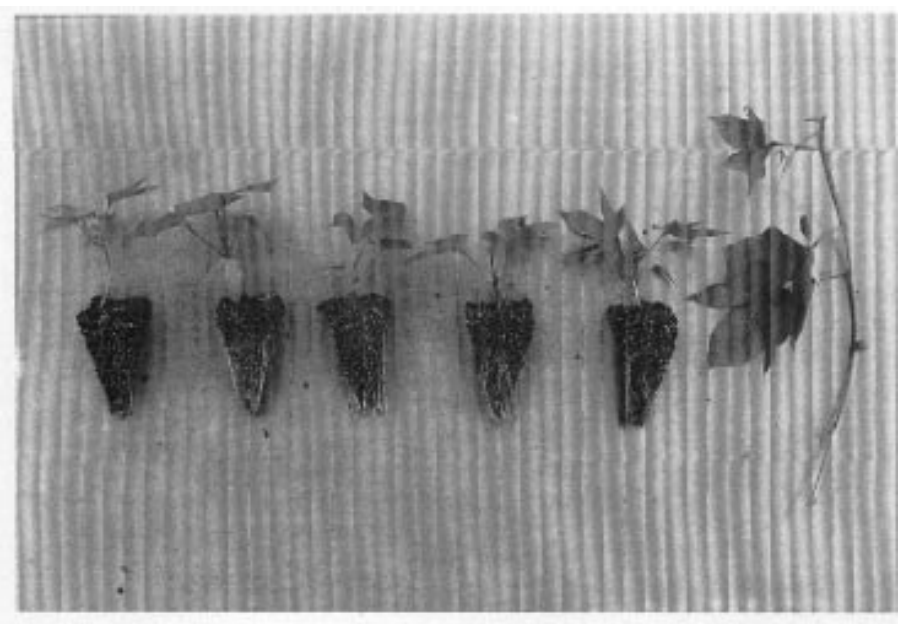

Fig. 1.Propagule sources and types evaluated in field experiments, from left to right include the following: 1) seedling derived from somatic embryo (SET), 2) seedling derived from zygotic seed (ZST), 3) nodal cutting derived from stock plant (SPE), 4) nodal cutting from plant derived from somatic embryo (SEE), 5) seedling obtained from stock plant through micropropagation (SPM), and 6) and 7) apical vine cutting derived from a stock plant either asexually (SPV) or through somatic embryogenesis (SEV). weeks. After 2 more weeks ( 5 weeks after plantlet induction), the plants attained sufficient size for moving into trays (Todd-planter "100" flats, Speedling, Sun City, Fla.) containing a peat and vermiculite mix (Vegetable plug-mix, O.M. Scotts and Sons Co., Marysville, Ohio). Immediately after transplanting, the plants were watered with $1 / 20$ strength MS solution, and trays fitted with wire frames were enclosed in clear plastic bags to form a miniature greenhouse to prevent desiccation (Chée et al., 1984). The trays were placed in a growth chamber at $27 \mathrm{C}$, with a 14 - to 10-h light/ dark photoperiod and a light intensity of $150 \mu \mathrm{E} \cdot \mathrm{m}^{-2} \cdot \mathrm{s}^{-1}$. Two weeks after plant growth had commenced ( 7 weeks after plantlet induction), the plastic bags were opened and plants were gradually acclimated to lower relative humidities over a 3-day period. Plants were moved to the greenhouse and temperatures were maintained at or above $20 \mathrm{C}$ for 2 to 3 weeks to facilitate further growth. Plants were hardened-off by reduced watering and placed outside the greenhouse for 1 week before transplanting the seedlings in the field. The total time from embryo selection to transplanting in the field was $\approx 10$ weeks (SET).

The second and third propagule types were obtained from transplants derived from excised nodes (SEE) or vine tip cuttings (SEV) which originated from somatic embryos. The plant material from somatic embryos (SEE) was obtained by transplanting several seedlings into large ( $25 \mathrm{~cm}$ in diameter) pots, and vegetative growth then was promoted by weekly fertilizer applications and a regular watering schedule. Plants were raised in growth chambers under a 14/10-h light/dark photoperiod, at a light intensity of 980 $\mu \mathrm{E} \cdot \mathrm{m}^{-2} \cdot \mathrm{s}^{-1}$ at $27 \mathrm{C}$. Transplants obtained for nodal propagation were made from one node stem cuttings $\approx 4 \mathrm{~cm}$ long (second somatic embryo propagule type), and planted into cells (Todd-planter "100" flats, Speedling) that contained soilless mix (Vegetable plug-mix, O.M. Scotts and Sons Co.). The excised nodes rooted under mist in $\approx 1$ week, grew into plants, and were transplanted into the field in 6 to 8 weeks (SEE). The third somatic embryo propagule type was obtained from regenerated plants grown and maintained in the greenhouse. These plants were maintained in a vegetative state and terminal vine cuttings $\approx 25$ to $30 \mathrm{~cm}$ were removed and transplanted directly into the soil (SEV).

The planting material from stock plants was obtained from excised nodes and terminal vine cuttings (as with somatic embryos). In addition, they were obtained via micropropagation. In this case, the propagules from stock plants were obtained from shoot tips which were maintained and proliferated in petri plates on $0.7 \%$ (w/v) agar-solidified basal medium supplemented with 30 $\mu \mathrm{M}$ benzylaminopurine and $87 \mathrm{~mm}$ sucrose. Plants were multiplied in vitro by cutting 4-mm shoot pieces, each containing a node, and placing them with the apex positioned upright on agar-solidified basal medium without growth regulators. Micropropagated plants were acclimated to a nonsterile environment in a similar manner as 
the seedlings obtained from somatic embryos (SET), except that they grew more vigorously and were ready for transplanting in the field in 6 weeks (SPM). As with propagules obtained from somatic embryos, the other two stock plant propagation treatments (five and six) were obtained from excised nodes (SPE) and terminal vine cuttings (SPV) from plants maintained in the greenhouse.

Plants from the zygotic seed (ZST) constituted the seventh treatment. Six weeks before field transplanting, seeds were scarified for $30 \mathrm{~min}$ in concentrated sulfuric acid, rinsed with tap water, and sown into cells (Todd-planter "100" flats, Speedling) containing soilless media as described above. All seven treatments were not used in each experiment since additional treatment comparisons were added in subsequent years.

\section{Experimental design and data collection}

The Gainesville experiments were conducted in 1986 on poorly drained Kanapaha fine sand (Loamy, silaceous, hyperthermic Grossarenic Paleaquult); in 1987 on poorly drained Placid fine sand that contained a thick $(20 \mathrm{~cm})$, organic rich $(\geq 1 \%)$ surface layer (Sandy, silaceous, hyperthermic Typic Humaquepts); and in 1988 on well-drained Arrendonda fine sand (Loamy, silaceous, hyperthermic Grossarenic Palenudult). In Homestead, the experiment was planted on Krome very gravelly loam (Loamy/skeletal, carbonatic, hyperthermic Lithic Rendalls). Planting and harvest dates of the experiments (Table 2) varied because of environmental conditions and availability of planting material. Seven field studies were planted, one in 1986 and three each in 1987 and in 1988. In order to reduce space, four representative experiments are presented. Experiments could not be combined because of slight variations in treatments and data collected. All experiments compared propagation types (Table 1) using a randomized completeblock design.

1986. In the 1986 study, Expt. 1, three propagation types were compared: SET, SEV, and SPV. Each treatment was replicated three times and had five plants per plot. Plant spacing in rows was $0.6 \mathrm{~m}$. For each treatment, five (one replication) and 10 (two replications) plants were harvested in the first and second harvests, respectively. Roots were graded according to diameter because this characteristic was previously determined to be the most important for assessing yields (Kays, 1985). Roots with diameters $\geq 2.5 \mathrm{~cm}$ were counted and weighed in the first harvest, while, for the second harvest, roots between 0.5 to 2.5 , and $\geq 2.5-\mathrm{cm}$ diameters were counted, and then total weight was determined.

1987. Three studies were conducted in 1987; however, data from only one experiment will be presented because results were similar between experiments. There were six treatments in Expt. 2: SET, SEE, SPE, SPV, SPM, and ZST. There were 12 replications; half of which were harvested early and half of which were harvested later (Table 2). Plots were $10 \mathrm{~m}$ long and contained 10 plants spaced $1 \mathrm{~m}$ apart.

Early plant growth data was measured by counting the number of nodes per plant (indicated by an expanded leaf) and measuring total plant vine length. Data were collected from three plant samples per plot at planting and at 2 and 4 weeks after planting. Roots were counted and weighed for each plant by separating the roots into three size categories: diameters of 0.5 to $2.5,2.5$ to 6.0 , and $6.0+\mathrm{cm}$.

1988. All seven treatments were included in the experiments conducted in 1988. In the Gainesville planting (Expt. 3), plot size and spacing were the same as in 1987. Treatments were replicated six times. In Homestead (Expt. 4), eight plants were established in plots that were $7.6 \mathrm{~m}$ long, and in-row spacing was $0.95 \mathrm{~m}$. Treatments in the Homestead planting were replicated five times. Replications varied between the Homestead and Gainesville locations because the number of plants from somatic embryos was limited. Three plant samples per plot were used to determine the number of nodes per plant and plant vine length at $0,2,3,6$, and/ or 9 weeks after planting. Roots were harvested at an early and a late date in Gainesville, while one harvest was obtained in Homestead (Table 2). Roots were graded on a whole-plot basis utilizing the same criteria mentioned previously for the 1987 experiments.

Statistical analysis. Data were analyzed using analysis of variance (ANOVA) techniques. Individual plant sampling measurements were employed for data acquisition to reduce sampling error. Statistical significance between growth and yield measurements was determined with SE analysis or Duncan's multiple range test.

\section{Results}

\section{Propagule source and type effects on early plant growth}

1986 study, Expt. 1. No plant growth measurements were obtained for this experiment.

1987 study, Expt. 2. At planting (0 weeks), the SET and the SPM had more nodes per propagule compared with the other propagule types (Table 3). However, 4 weeks after establishment, ZST had the most nodes per plant. Plants derived from the somatic embryo source had the fewest number of nodes per plant and the least vine growth (63\% to $84 \%$ less than the other propagation types) after 4 weeks.

1988 studies, Expts. 3 and 4. At planting (0 weeks), in Expt. 3, the number of nodes was greatest from SET (Table 4). After 2 weeks, most propagules grew an additional two to five nodes and increased up to $2 \mathrm{~cm}$ in length. Little or no vegetative growth was measured at 2 weeks when the propagule was a nonrooted apical vine cutting [(SEV or SPV) not a containerized transplant].

The difference in growth between propagules derived from

Table 2. Planting and harvest dates for experiments conducted in 1986, 1987, and 1988.

\begin{tabular}{|c|c|c|c|c|c|c|c|c|}
\hline \multirow[b]{2}{*}{ Year } & \multirow{2}{*}{$\begin{array}{c}\text { Expt. } \\
\text { no. }\end{array}$} & \multirow[b]{2}{*}{ City $^{z}$} & \multirow{2}{*}{$\begin{array}{c}\text { Planting } \\
\text { date }\end{array}$} & \multicolumn{2}{|c|}{ Harvest date(s) } & \multirow{2}{*}{$\begin{array}{c}\text { First } \\
\text { freeze }^{\mathrm{x}}\end{array}$} & \multicolumn{2}{|c|}{$\begin{array}{c}\text { Total days } \\
\text { until harvest }\end{array}$} \\
\hline & & & & Early $^{y}$ & Late & & Early & Late \\
\hline 1986 & 1 & G & 1 June & 15 Nov. & 8 Jan. & 2 Jan. & 168 & 221 \\
\hline 1987 & 2 & G & 29 May & 2 Dec. & $\mathrm{NH}^{\mathrm{w}}$ & 12 Nov. & 187 & $\mathrm{NH}$ \\
\hline 1988 & 3 & G & 4 Apr. & 29 Sept. & 22 Nov. & 2 Dec. & 178 & 232 \\
\hline 1988 & 4 & $\mathrm{H}$ & 31 Mar. & 16 Feb. & $\mathrm{NH}$ & None & 333 & $\mathrm{NH}$ \\
\hline
\end{tabular}

${ }^{\mathrm{z}} \mathrm{G}=$ Gainesville, $\mathrm{H}=$ Homestead.

yEarly harvest date is given for first or only harvest while a late harvest date is listed if applicable.

${ }^{\mathrm{x}}$ Irrigation was applied to plants during nights with freezing temperatures to protect plants in 1987; however, protection was not $100 \%$ and some plant damage occurred.

${ }^{w} \mathrm{NH}$ indicates no late harvest. 
Table 3. Effects of propagule source and type on the number of nodes and total vine length per plant when established ( 0 weeks), 2 , and 4 weeks after planting. Expt. 2, 1987, Gainesville. ${ }^{\mathrm{z}}$

\begin{tabular}{|c|c|c|c|c|c|c|c|}
\hline & & \multicolumn{3}{|c|}{ No. nodes/plant } & \multicolumn{3}{|c|}{ Vine length $(\mathrm{cm})$} \\
\hline \multicolumn{2}{|c|}{ Propagule $^{y}$} & \multicolumn{3}{|c|}{ Week } & \multicolumn{3}{|c|}{ Week } \\
\hline Source & Type & 0 & 2 & 4 & 0 & 2 & 4 \\
\hline SE & $\mathrm{T}$ & $8 a^{x}$ & $12 a b$ & 24 de & $6 \mathrm{~b}$ & $7 \mathrm{~b}$ & $24 \mathrm{c}$ \\
\hline SE & $\mathrm{E}$ & $2 \mathrm{c}$ & $5 \mathrm{~d}$ & $15 \mathrm{e}$ & $2 \mathrm{c}$ & $5 \mathrm{~b}$ & $28 \mathrm{c}$ \\
\hline ZS & $\mathrm{T}$ & $4 \mathrm{~b}$ & $14 \mathrm{a}$ & $53 \mathrm{a}$ & $3 \mathrm{c}$ & $9 \mathrm{~b}$ & $95 \mathrm{~b}$ \\
\hline SP & M & $7 \mathrm{a}$ & $10 \mathrm{bc}$ & $40 \mathrm{bc}$ & $6 \mathrm{~b}$ & $18 \mathrm{a}$ & $104 \mathrm{~b}$ \\
\hline SP & $\mathrm{E}$ & $2 \mathrm{c}$ & $7 \mathrm{~d}$ & $28 \mathrm{~cd}$ & $2 \mathrm{c}$ & $9 \mathrm{~b}$ & $76 b$ \\
\hline SP & $\mathrm{V}$ & $2 \mathrm{c}$ & $8 \mathrm{~cd}$ & $42 \mathrm{ab}$ & $13 \mathrm{a}$ & $21 \mathrm{a}$ & $148 \mathrm{a}$ \\
\hline
\end{tabular}

${ }^{\mathrm{z}}$ Data are averages of six replications from three plant samples.

yPropagule source; $\mathrm{SE}=$ somatic embryo, $\mathrm{ZS}=$ zygotic embryo (seed), $\mathrm{SP}$ $=$ stock plant. Propagule type; $\mathrm{T}=$ seedling transplant, $\mathrm{E}=$ rooted node cutting established as transplant, $\mathrm{M}=$ micropropagated established as a transplant, $\mathrm{V}=$ nonrooted apical vine cutting.

'Means separated within columns using Duncan's multiple range test, $P$

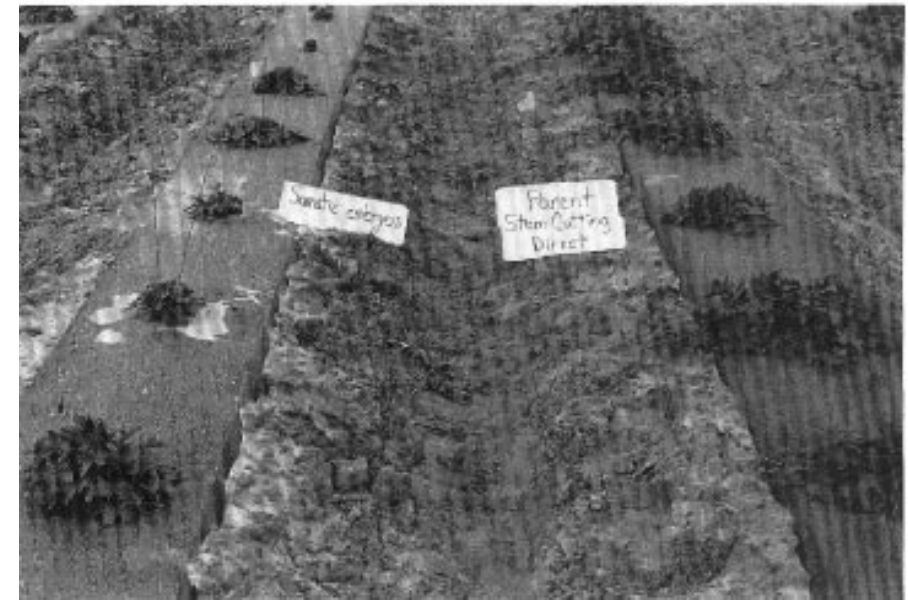

Fig. 2. Note the superior vegetative growth 6 weeks after planting in right row when plants were established from stock plants compared with reduced growth in the left row when plant material was derived from somatic embryos.

Table 4. Effects of propagule source and type on the number of nodes and total vine length per plant when initially established $(0$ weeks), 2, 6, and 9 weeks after planting. Expt. 3, 1988, Gainesville. ${ }^{\mathrm{z}}$

\begin{tabular}{|c|c|c|c|c|c|c|c|c|c|}
\hline & & \multicolumn{4}{|c|}{ No. nodes/plant } & \multicolumn{4}{|c|}{ Vine length $(\mathrm{cm})$} \\
\hline \multicolumn{2}{|c|}{ Propagule $^{y}$} & \multicolumn{4}{|c|}{ Weeks } & \multicolumn{4}{|c|}{ Weeks } \\
\hline Source & Type & 0 & 2 & 6 & 9 & 0 & 2 & 6 & 9 \\
\hline SE & $\mathrm{T}$ & $10 a^{x}$ & $12 \mathrm{a}$ & $70 \mathrm{ab}$ & $205 \mathrm{c}$ & $8 \mathrm{~b}$ & $9 \mathrm{c}$ & $60 c$ & $455 \mathrm{c}$ \\
\hline SE & $\mathrm{E}$ & $4 \mathrm{~b}$ & $6 \mathrm{bc}$ & $59 \mathrm{~b}$ & $255 \mathrm{bc}$ & $2 \mathrm{c}$ & $4 d$ & $93 \mathrm{c}$ & $1008 \mathrm{~b}$ \\
\hline SE & $\mathrm{V}$ & $5 \mathrm{~b}$ & $5 c$ & $55 \mathrm{~b}$ & $303 \mathrm{abc}$ & $19 \mathrm{a}$ & $19 \mathrm{~b}$ & $81 \mathrm{c}$ & $974 \mathrm{~b}$ \\
\hline $\mathrm{ZS}$ & $\mathrm{T}$ & $4 \mathrm{~b}$ & $9 \mathrm{~b}$ & $95 \mathrm{a}$ & $400 \mathrm{a}$ & $3 c$ & $5 \mathrm{~cd}$ & $166 \mathrm{~b}$ & $1180 \mathrm{~b}$ \\
\hline SP & $\mathrm{E}$ & $4 \mathrm{~b}$ & $8 \mathrm{~b}$ & $88 \mathrm{a}$ & $411 \mathrm{a}$ & $3 c$ & $5 \mathrm{~cd}$ & $245 \mathrm{a}$ & $2064 \mathrm{a}$ \\
\hline SP & $\mathrm{V}$ & $5 \mathrm{~b}$ & $5 \mathrm{c}$ & $76 \mathrm{ab}$ & $352 \mathrm{ab}$ & $22 \mathrm{a}$ & $23 \mathrm{a}$ & $169 \mathrm{~b}$ & $1763 \mathrm{a}$ \\
\hline
\end{tabular}

${ }_{\mathrm{Z}}$ Data are averages of 12 replications from three plant samples.

yPropagule source: $\mathrm{SE}=$ somatic embryo, ZS = zygotic embryo (seed), SP = stock plant. Propagule type: $\mathrm{T}=$ seedling transplant, $\mathrm{E}=$ rooted node cutting established as transplant, $\mathrm{M}=$ micropropagated established as a transplant, $\mathrm{V}=$ nonrooted apical vine cutting.

${ }^{x}$ Means separated within columns using Duncan's multiple range test at $P=0.05$.

Table 5. Effects of propagule source and type on the number of nodes and total vine length per plant when initially established (0 weeks), and 2, 3, and 9 weeks after planting. Homestead, Expt. 4, 1988. ${ }^{\mathrm{z}}$

\begin{tabular}{|c|c|c|c|c|c|c|c|c|c|}
\hline & & \multicolumn{4}{|c|}{ No. nodes/plant } & \multicolumn{4}{|c|}{ Vine length $(\mathrm{cm})$} \\
\hline \multicolumn{2}{|c|}{ Propagule $^{y}$} & \multicolumn{4}{|c|}{ Weeks } & \multicolumn{4}{|c|}{ Weeks } \\
\hline Source & Type & 0 & 2 & 3 & 9 & 0 & 2 & 6 & 9 \\
\hline SE & $\mathrm{T}$ & $10 a^{x}$ & $10 \mathrm{a}$ & $13 \mathrm{ab}$ & $260 \mathrm{a}$ & $12 \mathrm{~b}$ & $11 \mathrm{~b}$ & $15 \mathrm{~b}$ & $920 \mathrm{~b}$ \\
\hline SE & $\mathrm{E}$ & $4 \mathrm{~d}$ & $7 \mathrm{bc}$ & $10 \mathrm{bc}$ & $270 \mathrm{a}$ & $3 \mathrm{c}$ & $4 \mathrm{c}$ & $9 \mathrm{c}$ & $771 \mathrm{~b}$ \\
\hline SE & $\mathrm{V}$ & $7 \mathrm{~b}$ & $5 \mathrm{c}$ & $9 \mathrm{c}$ & $242 \mathrm{a}$ & $25 \mathrm{a}$ & $25 \mathrm{a}$ & $27 \mathrm{a}$ & $852 \mathrm{~b}$ \\
\hline ZS & $\mathrm{T}$ & $6 \mathrm{c}$ & $8 \mathrm{ab}$ & $16 \mathrm{a}$ & $329 \mathrm{a}$ & $4 \mathrm{c}$ & $8 \mathrm{bc}$ & $15 \mathrm{bc}$ & $1176 \mathrm{ab}$ \\
\hline SP & M & $7 \mathrm{~b}$ & $7 \mathrm{~b}$ & $11 \mathrm{bc}$ & $375 \mathrm{a}$ & $5 \mathrm{c}$ & $7 \mathrm{c}$ & $12 \mathrm{bc}$ & $1614 \mathrm{a}$ \\
\hline SP & $\mathrm{E}$ & $4 \mathrm{~d}$ & $6 \mathrm{bc}$ & $11 \mathrm{bc}$ & $294 \mathrm{a}$ & $3 c$ & $6 \mathrm{c}$ & $12 \mathrm{bc}$ & $1334 \mathrm{ab}$ \\
\hline SP & $\mathrm{V}$ & $5 \mathrm{~cd}$ & $7 \mathrm{~b}$ & $11 \mathrm{bc}$ & $263 \mathrm{a}$ & $9 \mathrm{~b}$ & $10 \mathrm{bc}$ & $16 \mathrm{~b}$ & $1251 \mathrm{ab}$ \\
\hline
\end{tabular}

${ }^{\mathrm{Z}}$ Data are averages of five replications from three plant samples.

yPropagule source: $\mathrm{SE}=$ somatic embryo, $\mathrm{ZS}=$ zygotic embryo (seed), $\mathrm{SP}=$ stock plant. Propagule type: $\mathrm{T}=$ seedling transplant, $\mathrm{E}=$ rooted node cutting established as transplant, $\mathrm{M}=$ micropropagated established as a transplant, $\mathrm{V}=$ nonrooted apical vine cutting.

xMeans separated within columns using Duncan's multiple range test at $P=0.05$.

somatic embryos vs. stock plants was easily distinguished at 6 weeks (Fig. 2). At 6 and 9 weeks, both the number of nodes per plant and total vine length were greater, regardless of propagule type, for plants derived from stock plants instead of somatic embryos (Table 4). At 6 and 9 weeks, propagules obtained from
ZST also produced plants with more nodes than plants from somatic embryos. However, ZST produced plants with shorter vines than plants from stock plants at 9 weeks.

In the Homestead study, Expt. 4, the number of nodes and vine length at planting were greater when the propagules were derived 
from somatic embryos either with SET or SEV compared to those derived from ZST or from SPE (Table 5). By week 9, most propagule types had a similar number of nodes per plant and vine length. Although differences in vine length and node production were generally not significant in this study, the trend was similar to that found in other studies in 1987 and 1988 in which plants obtained from stock plants or ZST grew more than those derived from somatic embryos.

\section{Yields as Affected by Propagule Source and Type}

1986 study. Few storage roots greater than $2.5 \mathrm{~cm}$ in diameter were produced by the early harvest from SET (Table 6) (Figs. 3 and 4). In comparison, yields (weight) of storage roots were over seven times greater when derived from stock plants compared to somatic embryos. Storage roots were greater in size when obtained from stock plants than from somatic embryos.

Storage root yields per plant increased when harvested 53 days later for all propagule types (Table 6). More roots were produced when somatic embryos were the propagule source, but the average root weight was three to four times less than roots from SPV. Thus, total root yields were still greater when plants were obtained from stock plants than from somatic embryos. Although root production varied among plants derived from SET after 221 days, large roots were produced from some SET, with roots weighing as much as 2.8 $\mathrm{kg}$ (Fig. 4). Average root size was reduced by the increase in total roots produced on plants derived from somatic embryos.

1987. In Expt. 2, SPV outyielded (total weight) SET, SEE, ZST, SPM, and SPE by at least $100 \%$ (Table 7). Yields were greater even though the total root number was lower when plants were established from SPV. Those plants derived through somatic embryogenesis were consistently the lowest yielding as most roots ranged between 0.5 to $2.5 \mathrm{~cm}$ in diameter, and few roots ever attained a diameter larger than $6.0+\mathrm{cm}$ after 187 days of growth in the field. More large roots were produced from zygotic seed or stock plant sources than somatic embryos, but plants derived from SPV produced heavier, larger roots compared with other propagation types. Containerized transplants derived from stock plant origin or from ZST produced lower yields than the SPV, but more than plants derived from somatic embryos.

1988 studies. In Expt. 3, for both the early and late harvests, plants propagated from SPV produced the greatest total weight and

Table 6. Effect of propagule source and type on root yields, early and late harvests, 1986, Expt. 1.

\begin{tabular}{|c|c|c|c|c|c|c|}
\hline \multicolumn{7}{|c|}{ Early harvest ${ }^{z}$} \\
\hline \multicolumn{2}{|c|}{ Propagule $^{y}$} & & Root no. ${ }^{\mathrm{x}}$ & \multicolumn{2}{|c|}{ Total yield/plant } & Avg kg/ \\
\hline Source & Type & & $\geq 2.5 \mathrm{~cm}$ in diameter & \multicolumn{2}{|c|}{$\mathrm{kg}$} & root \\
\hline SE & $\mathrm{T}$ & & $1.4 \pm 1 \mathrm{w}$ & \multicolumn{2}{|c|}{$0.27 \pm 0.27$} & $0.19 \pm 0.19$ \\
\hline SE & V & & $2.8 \pm 1$ & \multicolumn{2}{|c|}{$0.57 \pm 0.24$} & $0.22 \pm 0.07$ \\
\hline SP & V & & $7.2 \pm 1$ & \multicolumn{2}{|c|}{$3.77 \pm 0.39$} & $0.57 \pm 0.08$ \\
\hline \multicolumn{7}{|c|}{ Late harvest $t^{v}$} \\
\hline & & \multicolumn{2}{|c|}{ Root no. ${ }^{\mathrm{x}}$} & \multicolumn{2}{|c|}{ Total yield/plant } & Avg kg/ \\
\hline & & Small & Large & Root no. & $\mathrm{kg}$ & root \\
\hline SE & $\mathrm{T}$ & $13 \pm 2$ & $12 \pm 3$ & $25 \pm 3$ & $3.54 \pm 0.71$ & $0.14 \pm 0.03$ \\
\hline SE & $\mathrm{V}$ & $16 \pm 2$ & $21 \pm 3$ & $38 \pm 3$ & $3.77 \pm 0.53$ & $0.10 \pm 0.01$ \\
\hline SP & $\mathrm{V}$ & $5 \pm 1$ & $10 \pm 1$ & $15 \pm 1$ & $5.76 \pm 0.57$ & $0.40 \pm 0.04$ \\
\hline
\end{tabular}

ZPlants were harvested 168 days after planting. Data were averaged from five plants.

yPropagule source: $\mathrm{SE}=$ somatic embryo, $\mathrm{SP}=$ stock plant. Propagule type: $\mathrm{T}=$ seedling transplant, $\mathrm{V}=$ nonrooted apical vine cutting.

${ }^{x}$ Roots $\geq 2.5 \mathrm{~cm}$ were counted and weighed in the early harvest, while roots were graded by diameter into small $(0.5-2.5 \mathrm{~cm})$ and large $(2.5+\mathrm{cm})$ size categories in the later harvest.

${ }^{\mathrm{w}}$ Average mean $\pm \mathrm{SE}$.

vPlants were harvested 221 days after planting. Data were averaged from 10 plants.

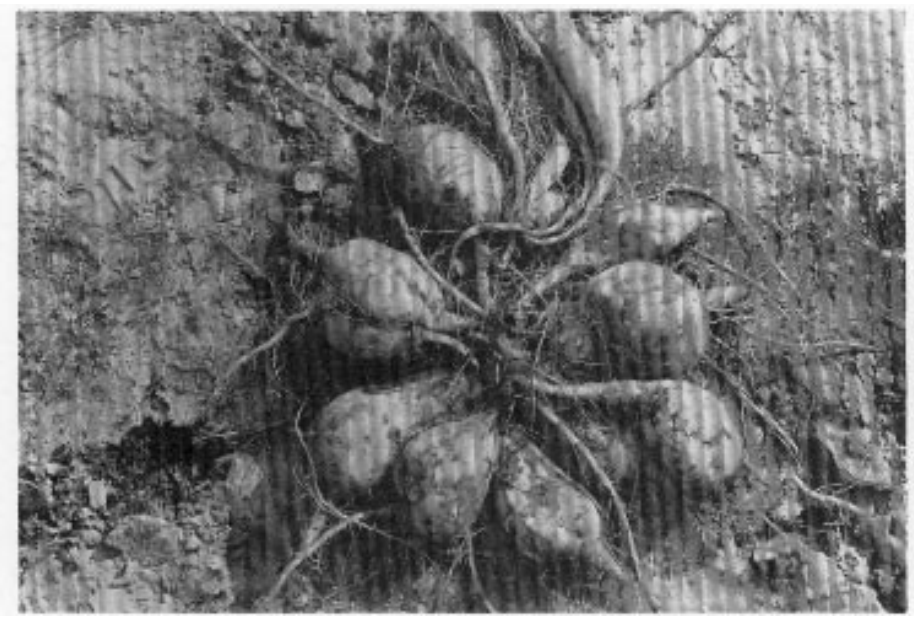

Fig. 3. An example of storage roots derived from a stock plant established from apical vine cutting (SPV).

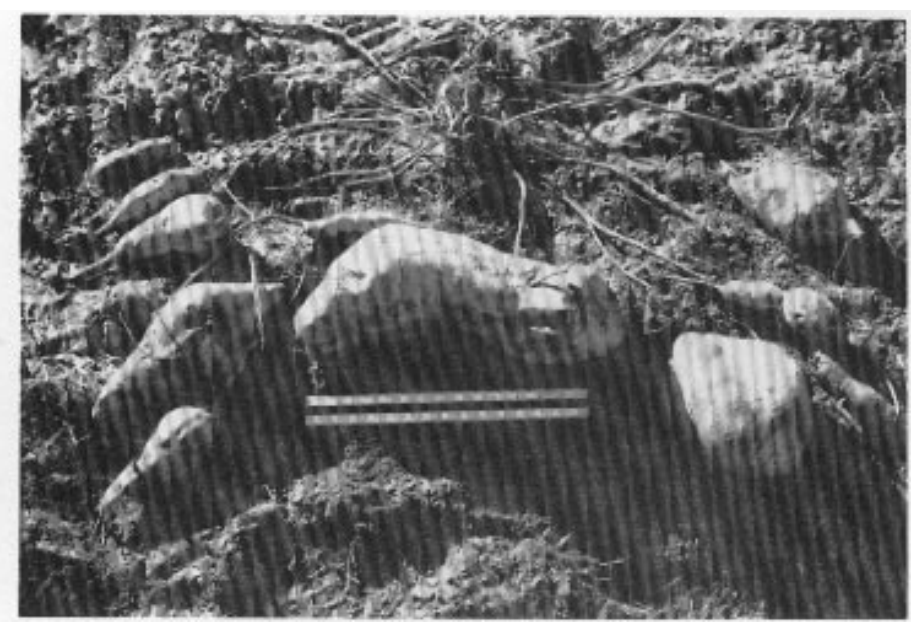

Fig. 4. An example of storage roots derived from a somatic embryo and established from a seedling transplant (SET). Note the large root in the center which weighed $2.8 \mathrm{~kg}$. 
Table 7. Effect of propagule source and type on root yields per plant graded into three size categories. Expt. 2, 1987. ${ }^{\mathrm{z}}$

\begin{tabular}{|c|c|c|c|c|c|c|c|c|c|c|c|c|}
\hline \multicolumn{2}{|c|}{ Propagule $^{y}$} & \multicolumn{3}{|c|}{ Small $^{\mathrm{x}}$} & \multicolumn{3}{|c|}{ Medium } & \multicolumn{3}{|c|}{ Large } & \multicolumn{2}{|c|}{ Total } \\
\hline Source & Type & no. & $\mathrm{kg}$ & $\mathrm{gm} / \mathrm{root}$ & no. & $\mathrm{kg}$ & $\mathrm{kg} / \mathrm{root}$ & no. & $\mathrm{kg}$ & $\mathrm{kg} / \mathrm{root}$ & no. & $\mathrm{kg}$ \\
\hline SE & $\mathrm{T}$ & $45 a b^{w}$ & $0.51 \mathrm{~b}$ & $11.7 \mathrm{~b}$ & $3 \mathrm{c}$ & $0.24 \mathrm{c}$ & $0.08 \mathrm{~b}$ & $0.1 \mathrm{e}$ & $0.02 \mathrm{~d}$ & $0.27 \mathrm{~b}$ & $48 \mathrm{bc}$ & $0.8 \mathrm{c}$ \\
\hline SE & $\mathrm{E}$ & $49 \mathrm{a}$ & $0.65 \mathrm{c}$ & $14.2 \mathrm{ab}$ & $7 \mathrm{~b}$ & $0.88 \mathrm{~b}$ & $0.09 \mathrm{ab}$ & $0.4 \mathrm{de}$ & $0.16 \mathrm{~cd}$ & $0.41 \mathrm{~b}$ & $56 \mathrm{ab}$ & $1.4 \mathrm{c}$ \\
\hline ZS & $\mathrm{T}$ & $24 \mathrm{~cd}$ & $0.32 \mathrm{c}$ & $14.4 \mathrm{a}$ & $14 \mathrm{a}$ & $1.46 \mathrm{a}$ & $0.11 \mathrm{a}$ & $2.0 \mathrm{bc}$ & $1.12 \mathrm{~b}$ & $0.56 \mathrm{~b}$ & $40 \mathrm{~cd}$ & $2.9 \mathrm{~b}$ \\
\hline SP & M & $56 \mathrm{a}$ & $0.72 \mathrm{a}$ & $13.6 \mathrm{ab}$ & $8 \mathrm{~b}$ & $0.75 \mathrm{~b}$ & $0.09 \mathrm{ab}$ & $1.1 \mathrm{~cd}$ & $0.68 \mathrm{bc}$ & $0.59 \mathrm{~b}$ & $65 \mathrm{a}$ & $2.1 \mathrm{~b}$ \\
\hline SP & $\mathrm{E}$ & $35 \mathrm{bc}$ & $0.47 \mathrm{~b}$ & $14.2 \mathrm{ab}$ & $9 \mathrm{~b}$ & $0.57 \mathrm{bc}$ & $0.10 \mathrm{a}$ & $2.3 \mathrm{~b}$ & $1.21 \mathrm{~b}$ & $0.55 \mathrm{~b}$ & $46 \mathrm{bc}$ & $2.6 \mathrm{~b}$ \\
\hline SP & V & $20 \mathrm{~d}$ & $0.25 \mathrm{c}$ & $12.8 \mathrm{ab}$ & $5 \mathrm{bc}$ & $0.60 \mathrm{bc}$ & $0.11 \mathrm{a}$ & $4.1 \mathrm{a}$ & $4.98 \mathrm{a}$ & $1.36 \mathrm{a}$ & $29 d$ & $5.8 \mathrm{a}$ \\
\hline
\end{tabular}

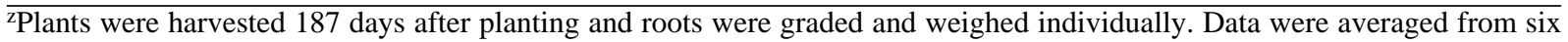
replications, each with 10 plant samples.

yPropagule source: $\mathrm{SE}=$ somatic embryo, $\mathrm{ZS}=$ zygotic embryo (seed), $\mathrm{SP}=$ stock plant. Propagule type: $\mathrm{T}=$ seedling transplant, $\mathrm{E}=$ rooted node cutting established as transplant, $\mathrm{M}=$ micropropagated established as a transplant, $\mathrm{V}=$ nonrooted apical vine cutting.

${ }^{x}$ Roots were graded by diameter into small $(0.5-2.5 \mathrm{~cm})$, medium $(2.5-6.0 \mathrm{~cm})$, and large $(6.0+\mathrm{cm})$ size categories.

${ }^{\text {w}}$ Means separated within columns using Duncan's multiple range test at $P=0.05$.

Table 8. Effect of propagule source and type on root yields graded into three size categories. 1988, Expt. 3, early and late harvests. ${ }^{\mathrm{Z}}$

\begin{tabular}{|c|c|c|c|c|c|c|c|c|c|c|c|c|}
\hline \multirow{2}{*}{\multicolumn{2}{|c|}{ Propagule $^{y}$}} & \multicolumn{11}{|c|}{ Yield per plant } \\
\hline & & \multicolumn{3}{|c|}{ Small $^{\mathrm{x}}$} & \multicolumn{3}{|c|}{ Medium } & \multicolumn{3}{|c|}{ Large } & \multicolumn{2}{|c|}{ Total } \\
\hline Source & Type & no. & $\mathrm{kg}$ & $\mathrm{gm} / \mathrm{root}$ & no. & $\mathrm{kg}$ & $\mathrm{kg} / \mathrm{root}$ & no. & $\mathrm{kg}$ & $\mathrm{kg} / \mathrm{root}$ & no. & $\mathrm{kg}$ \\
\hline \multicolumn{13}{|c|}{ Early harvest } \\
\hline SE & $\mathrm{T}$ & $43 \mathrm{a}^{\mathrm{w}}$ & $0.6 \mathrm{ab}$ & $15 \mathrm{a}$ & $2 \mathrm{c}$ & $0.10 \mathrm{~d}$ & $0.08 \mathrm{a}$ & $0.0 \mathrm{~b}$ & $0.0 \mathrm{c}$ & $--^{v}$ & $44 \mathrm{a}$ & $0.7 \mathrm{c}$ \\
\hline SE & $\mathrm{E}$ & $41 \mathrm{ab}$ & $0.8 \mathrm{a}$ & $19 \mathrm{a}$ & $1 \mathrm{c}$ & $0.07 \mathrm{~d}$ & $0.06 \mathrm{a}$ & $0.0 \mathrm{~b}$ & $0.0 \mathrm{c}$ & --- & $38 a b$ & $0.8 \mathrm{c}$ \\
\hline SE & V & $39 a b$ & $0.8 \mathrm{a}$ & $21 \mathrm{a}$ & $1 \mathrm{c}$ & $0.12 \mathrm{~cd}$ & $0.10 \mathrm{a}$ & $0.0 \mathrm{~b}$ & $0.0 \mathrm{c}$ & --- & $40 \mathrm{a}$ & $1.0 \mathrm{c}$ \\
\hline ZS & $\mathrm{T}$ & $16 \mathrm{c}$ & $0.3 \mathrm{~b}$ & $20 \mathrm{a}$ & $6 a$ & $0.70 \mathrm{a}$ & $0.11 \mathrm{a}$ & $2.3 \mathrm{a}$ & $1.3 \mathrm{~b}$ & $0.6 \mathrm{ab}$ & $25 \mathrm{~b}$ & $2.4 \mathrm{~b}$ \\
\hline SP & M & $32 \mathrm{ab}$ & $0.7 \mathrm{ab}$ & $21 \mathrm{a}$ & $5 a b$ & $0.37 \mathrm{~b}$ & $0.08 \mathrm{a}$ & $0.4 \mathrm{~b}$ & $0.1 \mathrm{c}$ & $0.4 \mathrm{~b}$ & $37 \mathrm{ab}$ & $1.2 \mathrm{c}$ \\
\hline SP & $\mathrm{E}$ & $35 \mathrm{ab}$ & $0.6 \mathrm{ab}$ & $17 \mathrm{a}$ & $3 \mathrm{bc}$ & $0.22 \mathrm{c}$ & $0.08 \mathrm{a}$ & $0.2 \mathrm{~b}$ & $0.2 \mathrm{c}$ & $0.7 \mathrm{ab}$ & $36 \mathrm{ab}$ & $0.8 \mathrm{c}$ \\
\hline SP & V & $27 \mathrm{bc}$ & $0.4 \mathrm{ab}$ & $10 \mathrm{a}$ & $4 \mathrm{~b}$ & $0.37 \mathrm{~b}$ & $0.10 \mathrm{a}$ & $2.2 \mathrm{a}$ & $2.7 \mathrm{a}$ & $1.3 \mathrm{a}$ & $33 a b$ & $3.5 \mathrm{a}$ \\
\hline \multicolumn{13}{|c|}{ Late harvest } \\
\hline SE & $\mathrm{T}$ & $36 \mathrm{ab}$ & $0.5 \mathrm{bc}$ & $13 \mathrm{c}$ & $2 b$ & $0.13 b$ & $0.09 \mathrm{~b}$ & $0.2 \mathrm{c}$ & $0.1 \mathrm{~d}$ & $0.30 \mathrm{~d}$ & $38 \mathrm{ab}$ & $0.7 \mathrm{e}$ \\
\hline SE & $\mathrm{E}$ & $49 \mathrm{a}$ & $0.9 \mathrm{a}$ & $19 \mathrm{a}$ & $4 a b$ & $0.40 \mathrm{a}$ & $0.11 \mathrm{~b}$ & $0.1 \mathrm{c}$ & $0.1 \mathrm{~d}$ & $0.39 \mathrm{~cd}$ & $52 \mathrm{a}$ & $1.4 \mathrm{~d}$ \\
\hline SE & V & $50 \mathrm{a}$ & $0.9 \mathrm{a}$ & $19 \mathrm{a}$ & $5 a b$ & $0.42 \mathrm{ab}$ & $0.08 \mathrm{~b}$ & $0.2 \mathrm{c}$ & $0.1 \mathrm{~d}$ & $0.48 \mathrm{bcd}$ & $55 \mathrm{a}$ & $1.4 \mathrm{~d}$ \\
\hline ZS & $\mathrm{T}$ & $10 \mathrm{c}$ & $0.2 \mathrm{c}$ & $19 \mathrm{a}$ & $4 a b$ & $0.48 \mathrm{ab}$ & $0.13 \mathrm{a}$ & $3.1 \mathrm{a}$ & $2.6 \mathrm{~b}$ & $0.85 \mathrm{~b}$ & $17 \mathrm{c}$ & $3.3 \mathrm{~b}$ \\
\hline SP & M & $24 \mathrm{bc}$ & $0.4 \mathrm{bc}$ & $16 \mathrm{bc}$ & $7 \mathrm{a}$ & $0.69 \mathrm{a}$ & $0.10 \mathrm{~b}$ & $1.6 \mathrm{~b}$ & $0.7 \mathrm{c}$ & $0.50 \mathrm{bcd}$ & $33 \mathrm{bc}$ & $1.8 \mathrm{~cd}$ \\
\hline SP & $\mathrm{E}$ & $38 \mathrm{ab}$ & $0.6 \mathrm{~b}$ & $15 \mathrm{c}$ & $7 \mathrm{a}$ & $0.74 \mathrm{a}$ & $0.10 \mathrm{~b}$ & $1.3 \mathrm{~b}$ & $1.0 \mathrm{c}$ & $0.77 \mathrm{bc}$ & $47 \mathrm{ab}$ & $2.3 \mathrm{c}$ \\
\hline SP & $\mathrm{V}$ & $26 \mathrm{bc}$ & $0.3 \mathrm{bc}$ & $14 \mathrm{c}$ & $4 a b$ & $0.40 \mathrm{ab}$ & $0.09 \mathrm{~b}$ & $2.9 \mathrm{a}$ & $3.5 \mathrm{a}$ & $1.27 \mathrm{a}$ & $33 \mathrm{bc}$ & $4.2 \mathrm{a}$ \\
\hline
\end{tabular}

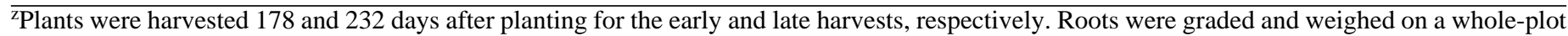
(10-plant) basis. Data were averaged from 3 replications, each with 10 plant samples.

'Propagule source; $\mathrm{SE}=$ somatic embryo, $\mathrm{ZS}=$ zygotic embryo (seed), $\mathrm{SP}=$ stock plant. Propagule type; $\mathrm{T}=$ seedling transplant, $\mathrm{E}=$ rooted node cutting established as a transplant, $\mathrm{M}=$ micropropagated established as a transplant, $\mathrm{NV}=$ nonrooted apical vine cutting.

xoots were graded by diameter into small $(0.5-2.5 \mathrm{~cm})$, medium $(2.5-6.0 \mathrm{~cm})$, and large $(6.0+\mathrm{cm})$ size categories.

${ }^{\text {w} M e a n s ~ s e p a r a t e d ~ w i t h i n ~ c o l u m n s ~ u s i n g ~ D u n c a n ' s ~ m u l t i p l e ~ r a n g e ~ t e s t ~ a t ~} P=0.05$.

${ }^{\mathrm{v}}$ No roots formed.

yield of large-sized roots (weight) (Table 8). The next best yielding (weight) propagule type was ZST, which had the fewest small-sized roots. Plants from somatic embryos consistently produced the lowest total yield (weight), and the lowest number and weight per plant of large-sized roots at both harvest dates. Even at the later harvest date, only a few medium- and large-sized roots were produced from somatic embryo origin. Thus, total yields were greater from stock plants compared with plants originating from somatic embryos. As was the case in the 1987 studies, plants obtained from ZST or SPV outyielded plants obtained through somatic embryogenesis.

In the Homestead study, Expt. 4, the favorable environmental conditions and the longer growing season (333 days) resulted in all propagules producing large-sized roots (Table 9). Although large-sized roots were obtained from plants derived through somatic embryony, the most large-sized roots, greatest weights per root and the greatest total yields were obtained from SPM and SPE plants. Individual large-sized roots obtained via SPM were nearly two times heavier than those from ZST, SET, or SEE.

\section{Discussion}

Templeton-Somers and Collins (1986) found that plants obtained in vitro from leaf margins, lateral buds, or nodes consistently produced lower yields than from slips or stem cuttings. In the present studies, the use of in vitro procedures, specifically somatic embryogenesis, also resulted in the lowest root weights compared to plants established with nonrooted vine cuttings. However, more roots were usually produced from plants obtained from somatic embryos.

Early plant growth and yield (weight) were significantly reduced when plants were obtained through somatic embryony 
Table 9. Effect of propagule source and type on root yields graded into three size categories, Homestead, $1988{ }^{\mathrm{z}}$

\begin{tabular}{|c|c|c|c|c|c|c|c|c|c|c|c|c|}
\hline \multicolumn{13}{|c|}{ Yield per plant } \\
\hline \multicolumn{2}{|c|}{ Propagule $^{y}$} & \multicolumn{3}{|c|}{ Small $^{x}$} & \multicolumn{3}{|c|}{ Medium } & \multicolumn{3}{|c|}{ Large } & \multicolumn{2}{|c|}{ Total } \\
\hline Source & Type & no. & $\mathrm{kg}$ & $\mathrm{g} /$ root & no. & $\mathrm{kg}$ & $\mathrm{g} /$ root & no. & $\mathrm{kg}$ & $\mathrm{kg} / \mathrm{root}$ & no. & $\mathrm{kg}$ \\
\hline $\mathrm{SE}$ & $\mathrm{T}$ & $19 a b^{w}$ & $0.53 \mathrm{ab}$ & $27 \mathrm{a}$ & $6 \mathrm{c}$ & $0.49 \mathrm{c}$ & $82 \mathrm{c}$ & $3 \mathrm{c}$ & $0.93 \mathrm{~d}$ & $0.29 \mathrm{~d}$ & $28 \mathrm{c}$ & $1.94 \mathrm{~d}$ \\
\hline SE & $\mathrm{E}$ & $19 a b$ & $0.45 \mathrm{ab}$ & $24 \mathrm{a}$ & $8 \mathrm{bc}$ & $0.68 \mathrm{bc}$ & $84 \mathrm{c}$ & $2 \mathrm{c}$ & $0.71 \mathrm{~d}$ & $0.36 \mathrm{~cd}$ & $28 \mathrm{bc}$ & $1.85 \mathrm{~d}$ \\
\hline SE & V & $26 a$ & $0.63 \mathrm{a}$ & $23 \mathrm{a}$ & $11 \mathrm{abc}$ & $0.93 \mathrm{bc}$ & $79 \mathrm{c}$ & $5 \mathrm{bc}$ & $2.05 \mathrm{~cd}$ & $0.48 \mathrm{bc}$ & $42 \mathrm{a}$ & $3.61 \mathrm{~cd}$ \\
\hline $\mathrm{ZS}$ & $\mathrm{T}$ & $13 \mathrm{~b}$ & $0.30 \mathrm{~b}$ & $27 \mathrm{a}$ & $12 \mathrm{abc}$ & $0.87 \mathrm{bc}$ & $78 \mathrm{c}$ & $4 \mathrm{bc}$ & $1.43 \mathrm{~d}$ & $0.34 \mathrm{~cd}$ & $29 \mathrm{bc}$ & $2.60 \mathrm{~d}$ \\
\hline SP & M & $19 \mathrm{ab}$ & $0.48 \mathrm{ab}$ & $25 \mathrm{a}$ & $13 \mathrm{abc}$ & $1.36 \mathrm{ab}$ & $108 \mathrm{a}$ & $10 \mathrm{a}$ & $7.86 \mathrm{a}$ & $0.78 \mathrm{a}$ & $42 \mathrm{abc}$ & $9.71 \mathrm{a}$ \\
\hline SP & $\mathrm{E}$ & $29 \mathrm{a}$ & 0.73 aа & $25 \mathrm{a}$ & $18 \mathrm{a}$ & $1.71 \mathrm{a}$ & $94 \mathrm{~b}$ & $11 \mathrm{a}$ & $6.01 \mathrm{ab}$ & $0.55 \mathrm{~b}$ & $58 \mathrm{a}$ & $8.45 \mathrm{ab}$ \\
\hline SP & V & $23 \mathrm{ab}$ & $0.59 \mathrm{ab}$ & $26 \mathrm{a}$ & $15 \mathrm{ab}$ & $1.28 \mathrm{ab}$ & $87 \mathrm{bc}$ & $8 a b$ & $4.18 \mathrm{bc}$ & $0.56 \mathrm{~b}$ & $46 \mathrm{ab}$ & $6.05 \mathrm{bc}$ \\
\hline
\end{tabular}

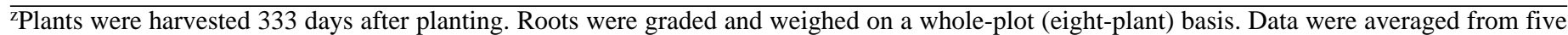
replications for each harvest.

yPropagule source: $\mathrm{SE}=$ somatic embryo, $\mathrm{ZS}=$ zygotic embryo (seed), $\mathrm{SP}=$ stock plant. Propagule type: $\mathrm{T}=$ seedling transplant, $\mathrm{E}=$ rooted node cutting established as transplant, $\mathrm{M}=$ micropropagated established as a transplant, $\mathrm{V}=$ nonrooted apical vine cutting.

${ }^{x}$ Roots were graded by diameter into small $(0.5-2.5 \mathrm{~cm})$, medium $(2.5-6.0 \mathrm{~cm})$, and large $(6.0+\mathrm{cm})$ size categories.

wMeans separated within columns using Duncan's multiple range test at $P=0.05$.

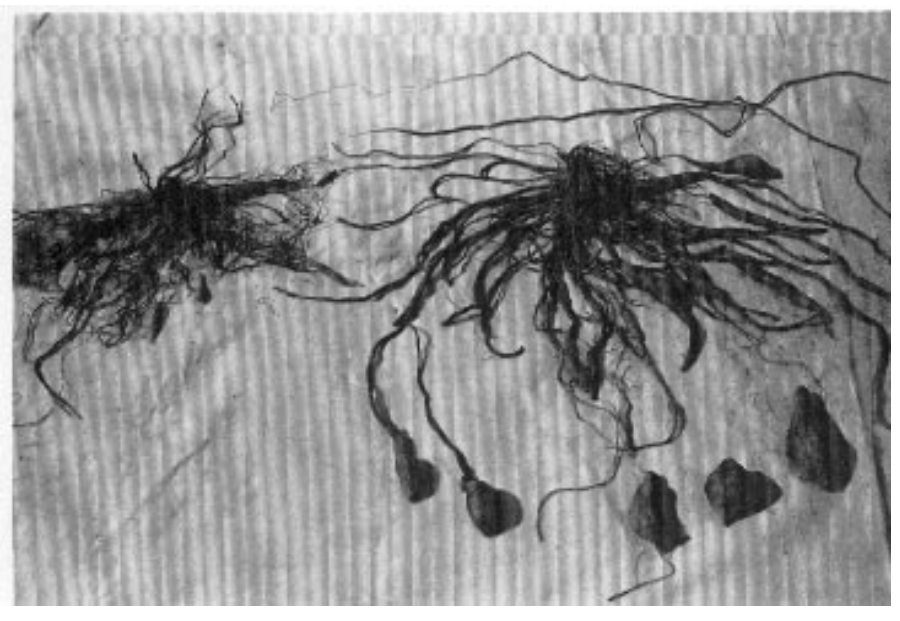

Fig. 5. Potential storage root production and enlargement of plants derived from somatic embryos. The plant on the left produced no storage roots while the plant on the right had begun to produce storage roots. Given optimal growing conditions, the swelled roots would likely have formed large-sized storage roots.

compared with stock plants. Reduced vegetative growth led to less root yields while greater vegetative growth led to greater root yields. Wilson (1982) proposed that root yields or sink capacity of a plant was directly related to the total number of cells which were meristematic or had storage capability. Lowe and Wilson (1974) determined that storage root initiation was completed by week 8 . Therefore, if overall plant growth is reduced, then storage root capability may also be reduced.

Generally, plants derived from somatic embryos produced a more compact plant than those from zygotic seed or stock plants (Fig. 2). This was due to a shorter internode length (data not presented). The reduced vegetative growth and root yields of plants from somatic embryos compared with stock plants could be attributed to a hormone imbalance in the plant. Hormones are one factor that might control the transition from the juvenile to the mature condition in woody and herbaceous plants (Hackett, 1983). In one study, the use of in vitro techniques has been reported to reduce storage root yields of sweetpotato in the initial growing season. However, when vegetative material was saved from the in vitro propagules and maintained over the winter, then replanted, the yields were comparable to those obtained when using slips or stem cuttings (Templeton-Somers and Collins, 1986). Thus, Templeton-Somers and Collins found the effect of propagation method had no effect on yields except for the initial growing season. It is possible that juvenility was a factor in the Templeton-Somers and Collins studies and in our studies.

In 1987, growing conditions were less favorable since temperatures were cold throughout the fall and freezing temperatures occurred early in November and shortened the growing season. Although the SET produced very few large-sized roots, the potential for their enlargement was apparent since root swelling had begun to occur in some of the plants at harvest (Fig. 5). The variation between plants, some with and some without root swelling, was possibly related to the variation observed in growth and vigor among seedlings while in culture, or undetected physiological differences in embryo development.

The relationship of tissue culture and the production of sporamin may have contributed to the low yields of plants derived from somatic embryos, a factor we did not investigate. Sporamin is the most abundant protein to accumulate in the sweetpotato root; however, when grown in tissue culture, this protein was found to accumulate in the stem in large amounts rather than the roots (Hattori, 1988). Sporamin is an important protein necessary for storage root formation and enlargement (Hattori, 1988). It is possible that high levels of sporamin were produced in the stem when plants were growing from somatic embryos in tissue culture. If this occurred, it may have caused a chemical imbalance in the plant and inhibited normal storage root production and their subsequent enlargement. The reduced yields obtained from tissueculture derived plants in our studies may also have been related to sporamin content.

Genetic fidelity of crop plants is often questioned when they are obtained through somatic embryogenesis. Several studies have examined the cytology, phenology, and reproduction capability of regenerated plants. Haydu and Vasil (1981) examined 70 napier grass (Pennisetum purpureum Schum.) plants regenerated from somatic embryos and found that plants were similar phenotypically to the donor plant. Root squashes also confirmed that regenerated plants had the normal complement of chromosomes. Corn plants regenerated from somatic embryos showed normal morphology, flowered, and set seed (Vasil et al., 1984). The normal chromosome number was observed in all plants examined. Armstrong and Green (1985) determined that four of 111 corn plants obtained from somatic embryos had either abnormal morphology or pollen sterility. Seed was produced by $77 \%$ of the regenerated plants. Liu and Cantliffe (1984) have observed that regenerated sweetpotato plants had normal vegetative and root morphology when grown in the greenhouse. Vasil (1987) con- 
cluded "that embryogenesis is a highly selective process that favors normal cells". In the present studies, other than shorter internodes during early plant growth and reduced storage root formation, sweetpotato plants produced from SET were identical to morphologically normal plants. Flowering was also observed on regenerated plants and was normal.

In a study that compared yields of napier grass plants derived from somatic embryos with asexual cuttings, Rajasekaran et al. (1987) found increased yields of vegetative tissue from somatic embryos. The authors attributed the higher yields from somatic embryos to the greater number of tillers produced from somatic embryos vs. asexual cuttings. In the present studies, storage root yields (weight) from somatic embryos were less than those derived from asexual cuttings from stock plants. However, some plants obtained from somatic embryos did show yield potential by producing large storage roots and more storage roots when grown under optimum growing conditions.

Normal production of storage roots for biomass must occur if commercial seeding of somatic embryos is to be ultimately successful. From the various environmental effects encountered in each study over the 3-year period, and with the somatic embryos currently available, it can be concluded that transplanted seedlings derived from somatic embryos require ideal growing conditions in order for normal production of storage roots. More rapid early plant growth must be obtained from somatic embryos as part of the successful implementation of a synthetic seeding planting program; otherwise, the grower will realize low yields. Yields are potentially great from somatic embryos given that these plants produced a greater number of small roots than those from zygotic seed or stock plant origin. However, the benefits of a planting system that utilizes somatic embryos will only be useful if the transport of starch synthesis can be increased in the additional roots produced by the somatic embryo-derived plants.

\section{Literature Cited}

Ammirato, P.V. 1983. Embryogenesis, p. 83-123. In: W.R. Sharp, P.V. Ammirato, and Y. Amide (eds.). Handbook of plant cell culture. vol. 1. Macmillan, New York.

Armstrong, C.L. and C.E. Green. 1985. Establishment and maintenance of friable, embryogenic maize callus and the involvement of L-proline. Planta 164:207-214.

Cantliffe, D.J., J.R. Liu, and J.R. Schultheis. 1987. Development of artificial seeds of sweet potato for clonal propagation through somatic embryogenesis, p. 183-195. In: W.H. Smith and J.R. Frank (eds.). Methane from biomass-a systems approach. Elsevier Applied Publ. Ltd. New York.

Chée, R., R.M. Pool, and D. Bucher. 1984. A method for large scale in vitro propagation of Vitis. New York Life Sci. Bul. 109:1-9.
Chée, R., J.R. Schultheis, and D.J. Cantliffe. 1990. Plant recovery from sweetpotato somatic embryos. HortScience 25:795-797.

Dangler, J.M., S.J. Locascio, and L.H. Halsey. 1984. Sweet potato for biomass. Biomass 4:253-261.

Fujii, A.A., D.T. Slade, K. Redenbaugh, and K.E. Walker, 1987. Artificial seeds for plant propagation. Bio/Technology 5:335-339.

Hackett, W.P. 1983. Phase change and intra-clonal variability. HortScience 18:840-844.

Hattori, T. 1988. Expression in transgenic tobacco of sporamin gene coding for the storage protein of sweet potato tuberous root. Israel Conf. Biotechnology No. 100.

Haydu, Z. and I.K. Vasil. 1981. Somatic embryogenesis and plant regeneration from leaf tissues and anthers of Pennisetum purpureum Schum. Theoretical Applied Genet. 59:269-273.

Kays, S.J. 1985. The physiology of yield in sweet potato, p. 79-132. In: J.C. Bouwkamp (ed.). Sweet potato products: a natural resource for the tropics. CRC Press. Boca Raton, Fla.

Linsmaier, E.M. and F. Skoog. 1965. Organic growth factor requirements of tobacco tissue cultures. Physiol. Plant. 18:100-127.

Liu, J.R. and D.J. Cantliffe. 1984. Somatic embryogenesis and plant regeneration in tissue cultures of sweet potato (Ipomoea batatas Poir.). Plant Cell Rpt. 3:112-115.

Lowe, S.B. and L.A. Wilson. 1974. Comparative analysis of tuber development in six sweet potato (Ipomoea batatas (L.) Lam) cultivars. 1. Tuber initiation, tuber growth, and partition of assimilate. Ann. Bot. 138:307-317.

Murashige, T. and F. Skoog. 1962. A revised medium for rapid growth and bioassays with tobacco tissue cultures. Physiol. Plant. 15:473-497.

O'Hair, S.K., S.J. Locascio, R.R. Forbes, J.M. White, D.R. Hensel, J.R. Shumaker, and J.M. Dangler. 1983. Root crops and their biomass potential in Florida. Soil Crop Soc. Fla. Proc. 42:13-17.

Rajasekaran, K., I.K. Vasil, and S.C. Schenck. 1987. Tissue culture of gramineous biomass species, p. 155-168. In: W.R. Smith and J.R. Frank (eds.). Methane from biomass-a systems approach. Elsevier Applied Sci. Publ., Ltd. New York.

Schultheis, J.R. and D.J. Cantliffe. 1992. Growth of somatic embryos of sweet potato (Ipomoea batatas (L.) Lam) in hydroxyethyl cellulose gel amended with salts and carbohydrates. Scientia Hort. 50:21-33.

Stall, W.M., G.W. Simone, F.A. Johnson, R.A. Dunn, and R.D. Williams. 1984. Sweet potatoes in Florida: A small farm production guide. Fla. Coop. Ext. Serv. Circ. 551.

Templeton-Somers, K.M. and W.W. Collins. 1986. Field performance and clonal variability in sweetpotatoes propagated in vitro. J. Amer. Soc. Hort. Sci. 111:689-694.

Tisseret, B., E. Easan, and T. Murashige. 1979. Somatic embryogenesis in angiosperms. Hort Rev. 1:1-78. AVI, Westport, Conn.

Vasil, I.K. 1987. Developing cell and tissue culture systems for improvement of cereal and grass crops. J. Plant Physiol. 128:193-218.

Vasil, V., I.K. Vasil, and C. Lu. 1984. Somatic embryogenesis in long-term callus cultures of Zea mays L. (Gramineae). Amer. J. Bot. 71:158-161.

Wilson, L.A. 1982. Tuberization in sweet potato (Ipomoea batatas (L.) Lam., p. 79-88. In: R.L. Villareal and T.D. Griggs (eds.). Asian Vegetable Research and Development Center. Shanhua, Taiwan. 